\title{
Development of a BALB/c mouse model of Helicobacter pylori infection with fresh and frozen bacteria
}

\author{
ELIZABETH M A RABELO-GONÇALVES*, NANCY F. NISHIMURA and JOSÉ \\ MURILO R ZEITUNE
}

Laboratory of Bacteriology, Gastrocenter, State University of Campinas-UNICAMP, Campinas, SP, Brazil

\begin{abstract}
An experimental model for $H$. pylori infection was established by intragastrically challenging BALB/c mice with $1 \mathrm{ml}\left(10^{8} \mathrm{CFU} / \mathrm{ml}\right)$ of suspension for two consecutive days. Animals were divided into three groups. GA: mice inoculated with fresh bacteria; GB: mice inoculated with frozen bacteria, and GC: mice inoculated with brucella broth (control group). Animals were killed at 7, 14, 21, 28, 35 and 60 days pi and fragments of stomach and duodenum were collected, paraffin embedded and stained by hematoxylin-eosin and Giemsa. The results showed that challenged mice exhibited mild duodenitis and gastritis. In group GA, infiltration in the duodenum was lymphoplasmacytic until day 35; in group GB, it was lymphomonocytic for 60 days pi. In the stomach, H. pylori induced lymphomonocytic infiltration that was present from days 7 to 60 in group GA. In group GB, it was only present from days 14 to 35 . In conclusion, our data suggested that freezing altered pathogenic properties of $H$. pylori and probably inhibited expression of bacterial antigens and consequently the establishment and maintenance of infection. Although the animals developed mild duodenitis and gastritis, the BALB/c mouse is not susceptible to developing peptic ulcers during $H$. pylori infection.
\end{abstract}

Key terms: BALB/c mouse, experimental model, Helicobacter pylori

\section{INTRODUCTION}

Helicobacter pylori is the most common bacterial pathogen found in the human gastrointestinal tract worldwide. Although noninvasive, this bacterium causes gastritis and peptic ulceration and has been linked to the development of gastric adenocarcinoma and lymphoma (Pappo et al., 1997 and Smythies et al., 2000).

The exact mechanisms of the pathogenesis of $H$. pylori infection are still not completely understood. Therefore, experimental models that mimic human disease are needed to provide information on etiopathogeny, immunity and therapy for this infection.

The first experimental models of $H$. pylori infection employed large animals that yielded important information, yet they were cumbersome, expensive, difficult to handle, and available only to a limited number of researchers (Lee et al., 1997). Some, such as gnotobiotic piglet, nonhuman primate, and cat models, have been the most successful in reproducing the pathology associated with human infection (Fox and Lee, 1997).

However, many researchers have developed a better animal model using small rodents such as the mouse and rat. These animals have the advantage of being easy to work with, widely available, and inexpensive, thus allowing a wide variety of experiments to be conducted (Karita et al., 1991). A further advantage is the ready availability of inbred strains, which decreases the number of animals needed to produce statistically meaningful results (Cantorna and Balish, 1989).

The gastritis induced in rat models of $H$. pylori infection appears to be generally less 
intense than in humans, as the rat is usually used to verify the influence of bacteria in ulcer healing and gastric physiology (Atuma et al., 1999; Konturek et al., 2000; Li et al., 1998; Ross et al., 1992). The Mongolian gerbil is another rodent model that has been successfully used in $H$. pylori experimental gastritis, peptic ulcer, and gastric cancer (Matsumoto et al., 1997; Wirth et al., 1998), although it is not widely available. Consequently, the mouse model is possibly more useful than the other models.

Karita and colleagues (1991) used athymic and euthymic BALB/c animals to establish the first experimental mouse model. The authors were the first to demonstrate that it was possible to colonize small laboratory animals with $H$. pylori.

More recent reports have been published on the colonization of immuno-competent mice with mouse-adapted $H$. pylori isolates (Ferrero et al., 1995; Marchetti et al., 1995; Ayraud et al., 2002) with fresh clinical H. pylori isolates (Marchetti et al., 1995; Lee et al., 1997; Ayraud et al., 2002; Guo and Mekalanos, 2002) and coccoid forms of $H$. pylori (Cellini et al., 1994; Aleljung et al., 1996; Wang et al., 1997; Hua et al., 1998; Rabelo-Gonçalves et al., 2002; She et al., 2003).

In the present study we developed a murine experimental model for $H$. pylori infection using BALB/c mice inoculated with two suspensions, one prepared with fresh bacteria and another with frozen bacteria isolated from a patient with gastric ulcers.

\section{MATERIALS AND METHODS}

\section{Animals}

Male BALB/c mice were 6-8 weeks old when challenged. They were obtained from Centro Multi-Institucional de BioterismoCEMIB, State University of CampinasUNICAMP, Campinas, SP, Brazil and maintained under Specific Pathogen Free (SPF) conditions. The animals were fed with a sterilized commercial rodent diet and with sterilized water ad libitum. They were maintained in an ordinary environment.
This study was performed with the approval of the Biological Institute/UNICAMP Ethical Committee for Animal Research (authorization 80-2, 1999).

\section{Bacterial isolation}

A clinical isolate of $H$. pylori obtained from a patient with several gastric ulcers was used in our study. The rapid urease test was positive for this patient. The strain was grown on a selective plate medium consisting of sterile sheep blood $(10 \% \mathrm{v} / \mathrm{v})$, Agar Technical No 3 (Oxoid Ltd, Basingstoke, UK) and Brain-Heart Infusion (BHI) (Difco Laboratories, Detroit, MI, EUA) containing $10 \mathrm{mg} / \mathrm{ml}$ Vancomycin, 5 $\mathrm{mg} / \mathrm{l}$ Trimethoprim lactate, 2500IU/1 Polymixin B (Skirrow's supplement, Oxoid). Plates were incubated in an anaerobic jar (Difco) for 5 days at $37^{\circ} \mathrm{C}$ under microaerophilic atmosphere (Microaerobac, Probac, São Paulo, SP, Brazil). After the bacteria were grown, they were identified by Gram staining and biochemical tests of urease, catalase and oxidase. The strain was confirmed as cag $\mathrm{A}^{+}$and $\mathrm{vacA}^{+}$by PCR.

\section{Bacterial inoculum}

After isolation on agar plates, one sample of the strain was inoculated in $150 \mathrm{ml}$ Brucella Broth (Difco) supplemented with 2\% fetal calf serum (FCS) (Difco) and incubated under microaerophilic atmosphere at $37^{\circ} \mathrm{C}$ with agitation for 48 hours. The bacterial inoculum was adjusted to a concentration of approximately $10^{8}$ organisms/ml (Shomer et al., 1998) and immediately used for inoculation. Another sample of the strain was kept in BHI medium (Difco) supplemented with $15 \%$ glycerol and frozen at $-80^{\circ} \mathrm{C}$ for 1 month. After this period, the sample was thawed and cultured on plate medium to prepare other bacterial inocula.

\section{Experimental design}

One hundred twenty-six mice were divided into three groups: In GA, 42 animals were inoculated intragastrically with $1 \mathrm{ml}$ of suspension prepared with fresh bacteria on two consecutive days after fasting overnight 
with an urethral pediatric probe $\mathrm{N}^{\circ} 04$ (Embramed, São Paulo, SP, Brazil).

In GB, 42 animals were inoculated in the same way, with $1 \mathrm{ml}$ of suspension prepared with frozen bacteria kept at $-80^{\circ} \mathrm{C}$ for one month. In $\mathbf{G C}$, the 42-animal control group was inoculated using the same technique and $1 \mathrm{ml}$ of Brucella broth.

Six to seven animals from each group were killed by spinal dislocation at 7, 14, $21,28,35$ and 60 days post-inoculation (pi). The stomach and duodenum were collected, washed with sterile saline, and divided for histopathological study.

\section{Histopathology}

Stomach and duodenum samples were fixed in neutral $12 \%$ formalin and processed in the usual way for paraffin embedding. Multiple 5-micrometer-thick sections were stained by hematoxylin-eosin (H\&E) and Giemsa staining. The histopathological changes evaluated were the site of inflammation (corpus, antrum, duodenum), its composition (lymphomonocytic, lymphoplasmacytic), intensity (mild, moderate, marked), level of the infiltrate in the gastric and duodenal wall, the presence of erosions or ulceration, and the presence of gastritis and/or duodenitis (Cellini et al., 1994 and Dixon et al., 1996). In the smears stained by Giemsa, the presence of $H$. pylori in the stomach was assessed using immersion (X1000). The statistical difference between the inoculated groups (GA and GB) and the control group (GC) was compared by Fischer's Exact test and considered significant at values of $p \leq 0.05$.

\section{RESULTS}

\section{Macroscopic findings}

No visible gastrointestinal alterations were seen in the mice challenged with $H$. pylori in the GA and GB groups.

\section{Microscopic findings}

No erosion, ulceration or areas with gastric metaplasia in duodenum were seen in the gastrointestinal tract of inoculated animals (groups GA and GB). The histopathological analysis of the mice stomachs demonstrated that fresh $H$. pylori (group GA) was able to induce mild gastritis from days 14 through $60 \mathrm{pi}$, while in the GB group, gastric inflammation persisted only until day 35 (Fig. 1: antrum and corpus). In the antrum of animals in the GA group, a significant infiltration was seen at day 21 pi $(\mathrm{p}=0.026)$ (Fig. 1: antrum). The infiltration was primarily lymphomonocytic and was present in the lamina propria, submucosa and serosa. A lower degree of polymorphonuclear infiltration was seen in the lamina propria. In the gastric body, the inflammatory changes were significantly observed at days 14 $(\mathrm{p}=0.016)$ and 21 (0.033) pi (Fig. 1: corpus). The infiltration was mild and typically lymphomonocytic in groups GA and GB, but on day 21 it became moderate and was seen in the mucosa, lamina propria, submucosa and serosa of gastric corpus in group GA, although the submucosa was more affected (Fig. 2).

In the duodenum, the inflammatory cells were present from the initial period of infection in both experimental groups, up to day 60 (Fig. 1: duodenum). From day 21 to day 35, all mice in group GA developed duodenitis (Fig. 1: duodenum). Infected animals presented mild duodenitis in both challenged groups (Figs. 3 and 4). Some inoculated animals exhibited ballooning of the villi and capillary congestion in the duodenal mucosa in both inoculated groups (Fig. 3). Although the infiltration was visualized at the duodenal mucosa, including the villi, mice challenged with fresh clinical isolate (group GA) exhibited a typically lymphoplasmacytic infiltration from day 7 to day 35 (Fig. 4). In group GB the infiltrate was lymphomonocytic during all periods of infection.

The control mice challenged with Brucella broth demonstrated a welldeveloped gastric mucosa with specialized cells and normal foveolar surface. The only histological changes were a minimal number of inflammatory cells in the stomach and duodenum.

Additionally, in the infected animals that presented inflammatory infiltrate, the 


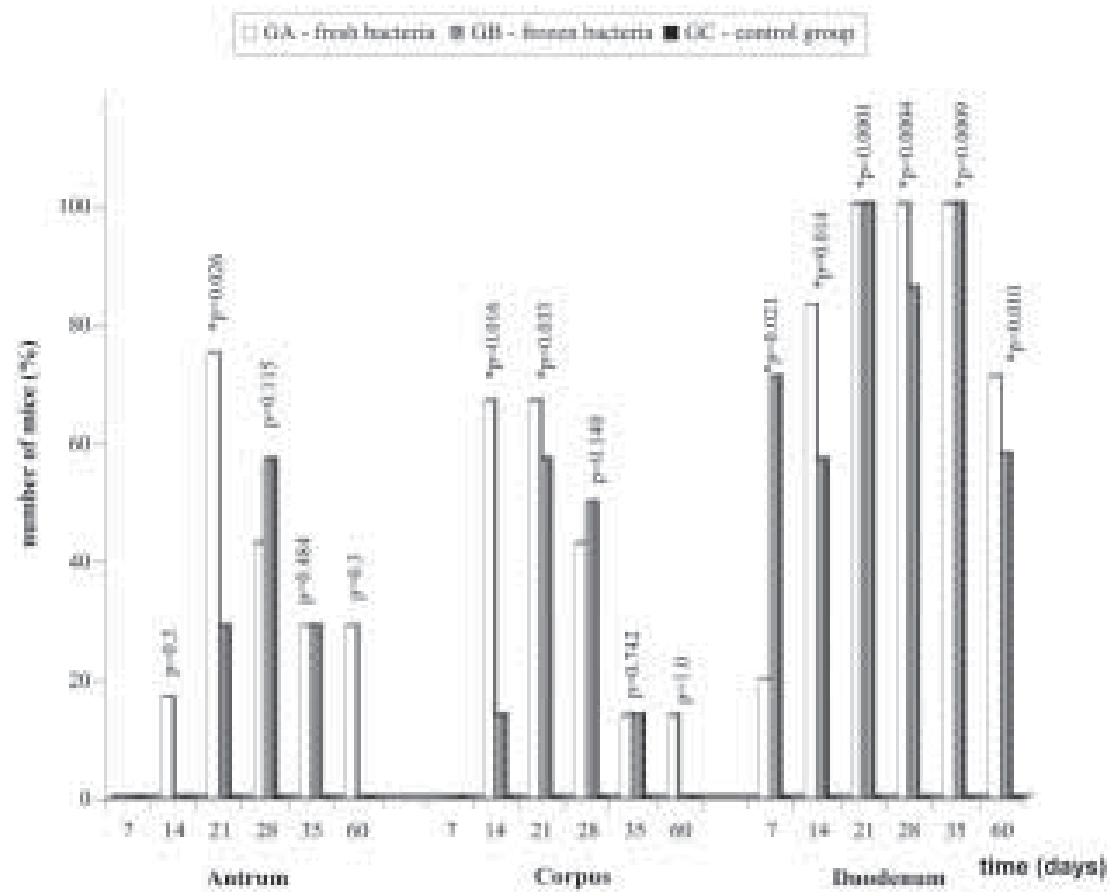

Figure 1. Number of mice (\%) with inflammatory infiltration in the gastric antrum, corpus, and duodenum. Comparison of challenged animals among experimental groups (GA, GB, and GC). $* p$-value statistically significant $(\mathrm{p} \leq 0.05)$

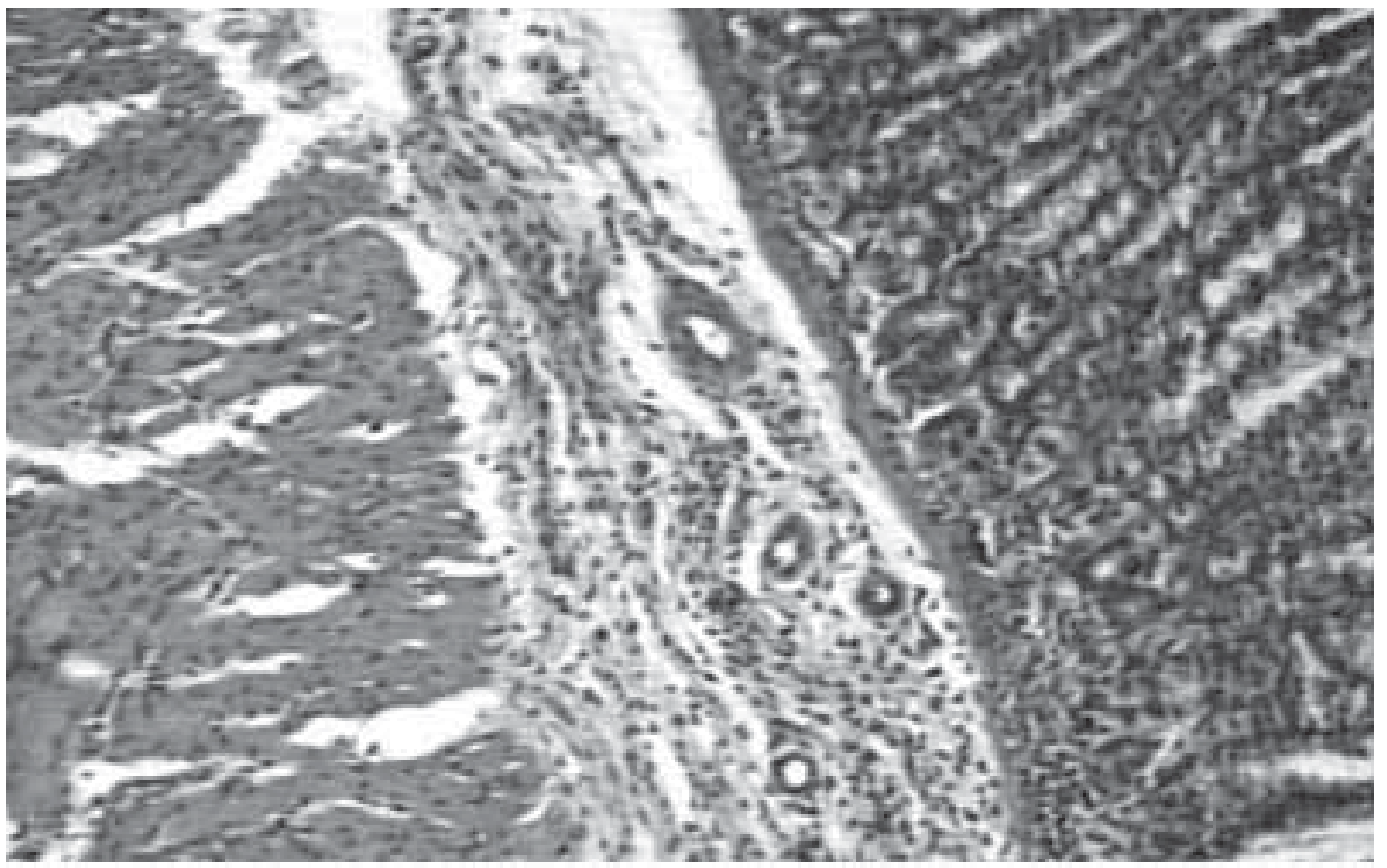

Figure 2. Moderated lymphomonocytic infiltration in the gastric body of mice inoculated with fresh $H$. pylori (group GA) at day 21 pi. Note inflammatory cells mainly in the submucosa, although they can be seen in the deeper mucosa and lamina propria. H\&E. X200. 


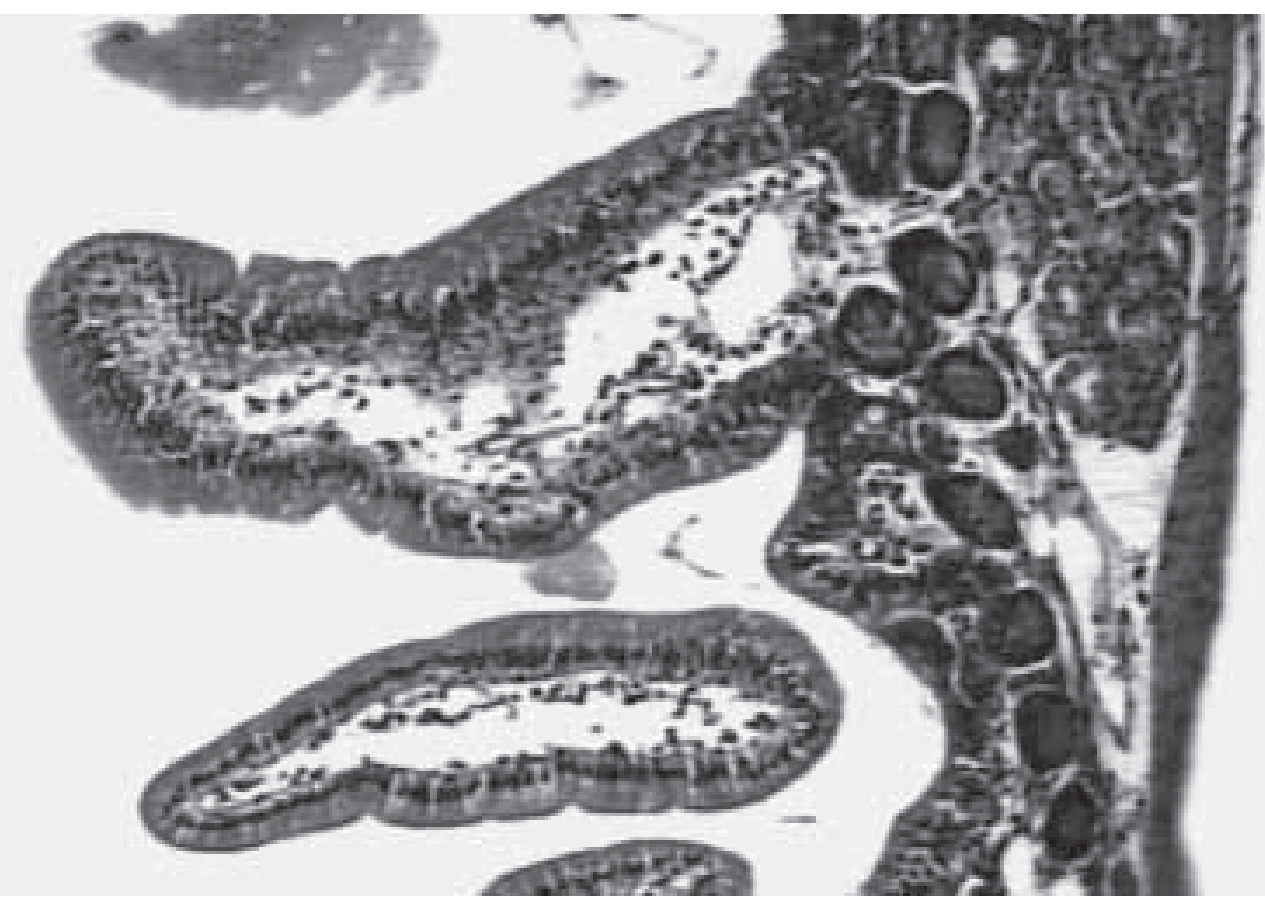

Figure 3. Mild inflammatory infiltration and ballooning of the villi at day 14 pi in the duodenal mucosa of a mouse challenged with frozen bacteria (group GB). H\&E. X100.

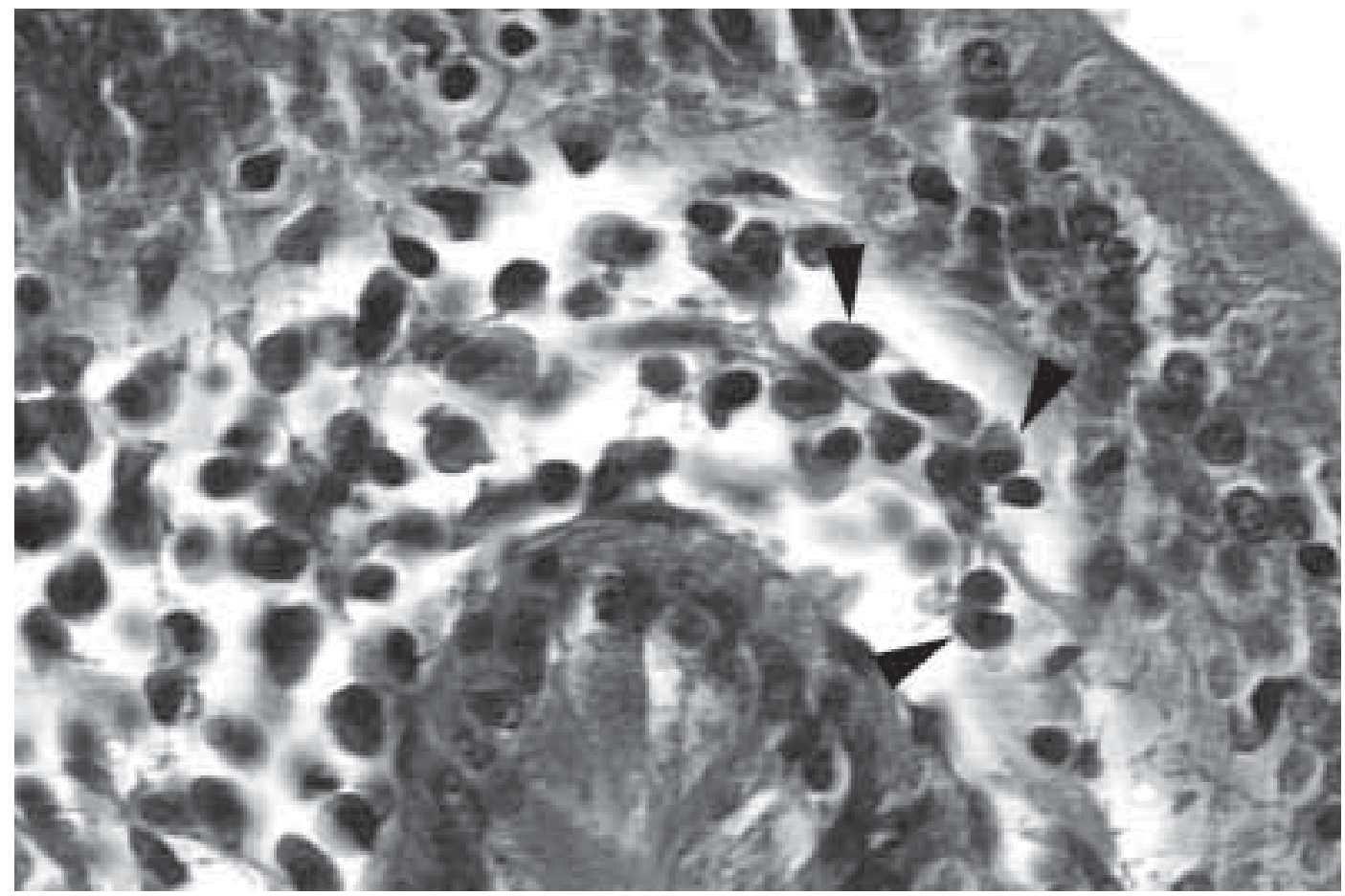

Figure 4. Mild lymphoplasmacytic infiltration in the duodenal mucosa of mouse challenged with fresh bacteria (group GA) at day 14 pi. Note plasma cells (arrows). H\&E. X1000. 
biopsies stained by Giemsa procedure primarily showed $H$. pylori in the mucus and upper foveolae of gastric antrum (Fig. 5). The bacteria were present throughout the experimental period (from day 7 through day 60).

\section{DISCUSSION}

In the present study we attempted to establish an experimental murine model for $H$. pylori infection using $\mathrm{BALB} / \mathrm{c}$ mice and a clinical isolate of bacteria. The animals were challenged with two suspensions prepared with fresh and frozen bacteria. Although many authors have suggested that success in reproducing human $H$. pylori infection also depends on the use of fresh clinical isolates, we employed frozen bacteria to evaluate whether freezing would alter the pathogenic properties of $H$. pylori.

The establishment of $H$. pylori experimental infection using fresh clinical isolates depends on factors such as the availability of a specialized center for diagnostic upper gastrointestinal endoscopy, selection of appropriate patients for primary isolation of bacteria, success in the primary isolation, and the availability of animals at the right age for inoculation. These factors would make employing frozen strains an advantage for the establishing the experimental H. pylori infection.

However, the histopathological findings described here showed that freezing had probably altered some of the pathogenic properties of $H$. pylori. In group GB, gastritis persisted from day 14 through day 35, while animals challenged with fresh bacteria (group GA) exhibited gastric inflammation for 60 days pi. Duodenitis in group GB demonstrated that freezing may have inhibited the expression of $H$. pylori antigens, which resulted in a reduced number of plasma cells primarily seen in the animals of the GA group (Fig. 4). Considering these results, we believe that some alterations occurred in the structural or biochemical characteristics of $H$. pylori during its freezing and further culture.

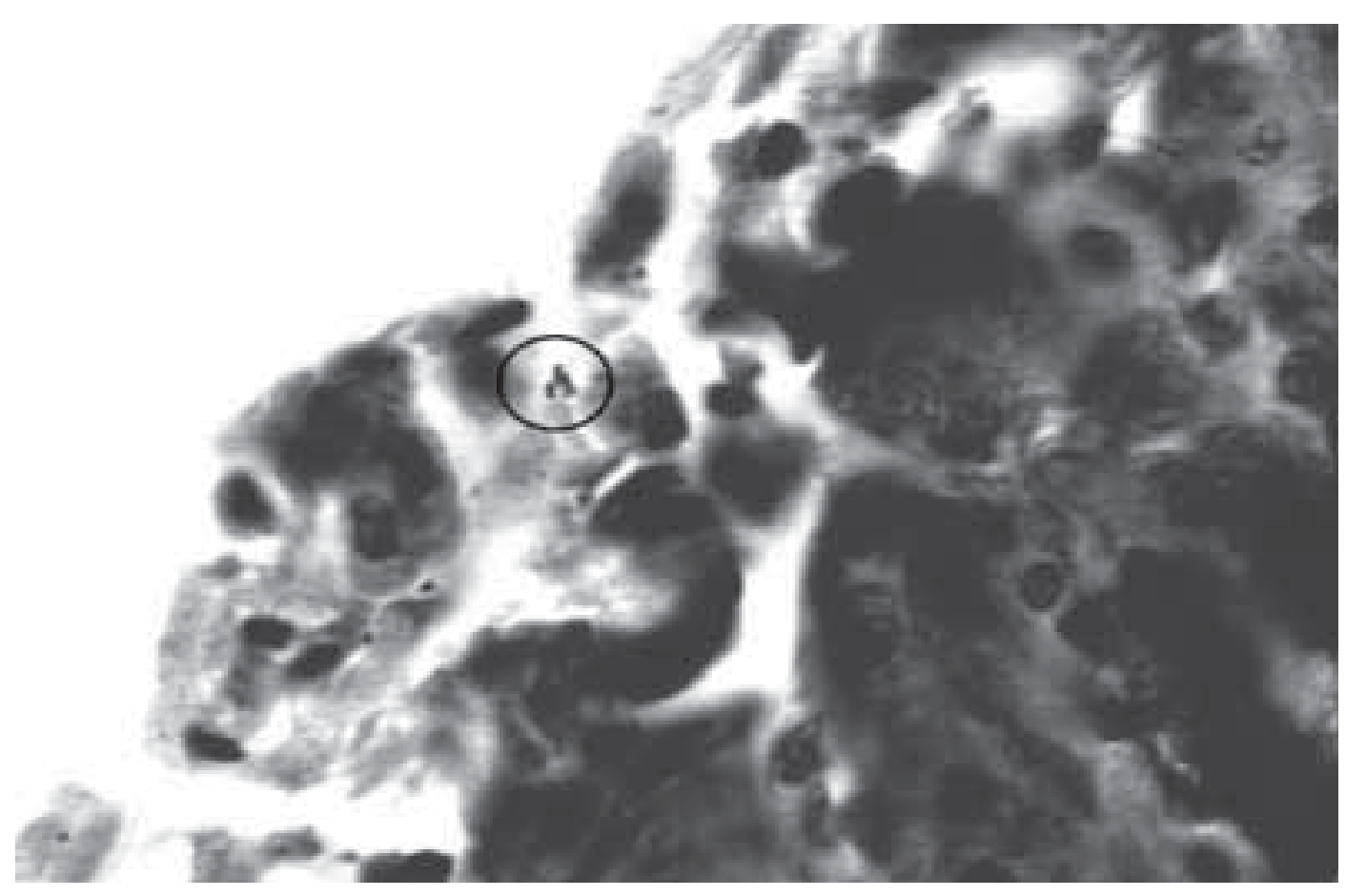

Figure 5. Presence of Helicobacter pylori (circle) in the antral gastric mucus of mouse inoculated with fresh bacteria (group GA) at day 21 pi. Giemsa. X1000. 
Similar findings were reported by Karita et al. (1991).

We also observed a difference in the appearance of gastritis in our murine model of $H$. pylori infection compared with the patterns of active gastritis observed in humans. Our results demonstrated that gastritis was primarily chronic, with a predominance of lymphocytes and very few polymorphs. Another important difference was that there was a lower degree of infiltration in the murine lamina propria by polymorphonuclear cells during the initial period of infection. These observations were confirmed by other authors and might be a result of variations in host reactivity to infection (Marchetti et al., 1995; Lee et al., 1997).

The analysis of gastric histopathology allowed us to observe that while $H$. pylori almost exclusively colonized the antrum, the inflammatory changes were primarily seen in the gastric body. These findings have been described by other authors (Sakagami et al., 1996).

Both bacterial virulence factors and the host's inflammatory response will contribute to mucosal damage in $H$. pylori infection. Considering the virulence factors of bacteria, several reports have suggested that $H$. pylori strains that possess the cytotoxin-associated gene ( $\operatorname{cagA}$ ) and secrete the vacuolating cytotoxin (VacA) are more virulent and related to the severity of gastrointestinal symptoms in humans (Figura et al., 1998; Audibert et al., 2001; Dundon et al., 2001; Muller et al., 2002) and mice (Telford et al., 1994).

In contrast with these studies, other authors have demonstrated that the clinical outcome of $H$. pylori infection is independent of $\operatorname{cagA}$ and $v a c \mathrm{~A}$ expression in humans (Yamaoka et al., 1999) as well as in mice (Ayraud et al., 2002; Wang et al., 2003). Our data confirm these findings as the strain we used in our model was confirmed as $c a g \mathrm{~A}^{+}$and $v a c \mathrm{~A}^{+}$by PCR, and inoculated animals did not develop marked gastritis or peptic ulcers. This emphasizes the fact that strain characteristics other than cagA and $v a c \mathrm{~A}$ determine the severity of infection.

Our histopathological data, however, have demonstrated that challenged animals in both groups (GA and GB) exhibited a ballooning of the villi. Several researchers have discussed the role of vacuolating cytotoxin in the gastrointestinal mucosa injury, including ballooning of the duodenal villi in mice challenged with $H$. pylori and the filtrate of bacterial fluid (Karita et al., 1991).

Although $H$. pylori only colonizes the gastric mucosa and areas with gastric metaplasia in the duodenum, the present study shows that the bacteria were able to induce duodenitis in mice. As $H$. pylori antigens are present in the feces of infected individuals (Kato et al., 2003), it seems possible that bacteria or their byproducts present in the luminal content activate duodenal $\mathrm{T}$ cells and that inflammatory alterations may occur. Studying the secretion of cytokines in children infected with H. pylori, authors observed that the colonization of the gastric mucosa induces a dysregulation of the mucosal immunity at distant sites, notably within the duodenal mucosa (Bontems et al., 2003).

These observations suggest that although bacterial factors are critical in the establishment and maintenance of infection, the genetic composition of the host, perhaps in combination with environmental factors, may also be important in determining the clinical manifestations of $H$. pylori infection (Kim et al., 2001). In fact, the inoculation of different strains of mice with bacteria has previously demonstrated that the host's genetic background is the major factor that contributes to the pathology associated with this infection (Mohammadi et al., 1996; Sakagami et al., 1996; Kim et al., 2001;).

In conclusion, our data demonstrated that although animals developed duodenitis and gastritis, BALB/c mice are not susceptible to developing peptic ulcers during $H$. pylori experimental infection.

\section{ACKNOWLEDGEMENTS}

We wish to express our special thanks to Dr. José Augusto Gatto Stedile and Dr. Luciana Meirelles for their excellent histopathological assistance and to Marilia A. Rabelo Buzalaf 
for valuable suggestions regarding the preparation of the manuscript. This work was supported by Fundação de Amparo à Pesquisa do Estado de São Paulo/Fapesp, Grant 99/ 07821-0, from São Paulo, Brazil.

\section{REFERENCES}

ALELJUNG P, NILSSON HO, WANG X, NYBERG P, MORNER T, WARSAME I, WADSTROM T (1996) Gastrointestinal colonization of BALB/cA mice by Helicobacter pylori monitored by heparin magnetic separation. FEMS Immunol Med Microbiol 13:303-309

ATUMA C, ENGSTRAND L, HOLM L (1999) Helicobacter pylori extracts reduce mucosal blood flow by a nitric oxide-independent but mast cell- and platelet-activating factor receptor-dependent pathway in rats. Scand J Gastroenterol 34:1183-1189

AUDIBERT C, BURUCOA C, JANVIER B, FAUCHERE JL (2001) Implication of the structure of the Helicobacter pylori cag pathogenicity island in induction of interleukin-8 secretion. Infect Immun 69:1625-1629

AYRAUD S, JANVIER B, FAUCHERE JL (2002) Experimental colonization of mice by fresh clinical isolates of Helicobacter pylori is not influenced by the cag A status and the vacA genotype. FEMS Immunol Med Microbiol 34:169-172

BONTEMS P, ROBERT F, VAN GOSSUM A, CADRANEL S, MASCART F (2003) Helicobacter pylori modulation of gastric and duodenal mucosal $\mathrm{T}$ cell cytokine secretions in children compared with adults. Helicobacter 8:216-226

CANTORNA MT, BALISH E (1989) Inability of the human clinical strains of Helicobacter pylori to colonize the alimentary tract of germfree rodents. Can J Microbiol 36:237-241

CELLINI L, ALLOCATI N, ANGELUCCI D, IEZZI T, Di CAMPLI E, MARZIO L, DAINELLI B (1994) Coccoid Helicobacter pylori not culturable in vitro reverts in mice. Microbiol Immunol 38:843-850

DIXON MF, GENTA RM, YARDLEY JH, CORREA P (1996) Classification and grading of gastritis. The updated Sydney System. International Workshop on the histopathology of gastritis, Houston 1994. Am J Surg Pathol 20:1161-1181

DUNDON WG, DE BERNARD M, MONTECUCCO C (2001) Virulence factors of Helicobacter pylori. Int J Med Microbiol 290:647-658

FERRERO RL, THIBERGE JM, KANSAU I, WUSCHER $\mathrm{N}$, HUERRE M LABIGNE A (1995) The GroES homolog of Helicobacter pylori confers protective immunity against mucosal infection in mice. Proc Natl Acad Sci 92:6499-6503

FIGURA N, VINDIGNI C, PRESENTI L (1998) New acquisitions in Helicobacter pylori characteristics. Ital J Gastroenterol Hepathol 30:S254-258

FOX JG, LEE A (1997) The role of Helicobacter species in newly recognized gastrointestinal tract diseases of animals. Lab Anim Sci 47:222-255

GUO BP, MEKALANOS JJ (2002) Rapid genetic analysis of Helicobacter pylori gastric mucosal colonization in suckling mice. Proc Natl Acad Sci 99:8534-8539

HUA JS, BOW H, ZHENG PY, YEOH GK, NG CH, LIM GS (1998) Coexistence of Helicobacter pylori spiral and coccoid forms in experimental mice. World $\mathrm{J}$ Gastroenterol 4:485-488
KARITA M, KOUCHIYAMA T, OKITA K, NAKAZAWA $T$ (1991) New small animal model for human gastric Helicobacter pylori infection: success in both nude and euthymic mice. Am J Gastroenterol 86:1596-1603

KATO S, OZAWA K, OKUDA M, FUJISAWA T, KAGIMOTO S, KONNO M, MAISAWA S, IINUMA K (2003) Accuracy of the stool antigen test for the diagnosis of childhood Helicobacter pylori infection: a multicenter Japanese study. Am J Gastroenterol 98:296-300

KIM JS, CHANG JH, CHUNG SI, YUM JS (2001) Importance of the host genetic background on immune responses to Helicobacter pylori infection and therapeutic vaccine efficacy. FEMS Immunol Med Microbiol 31:41-46

KONTUREK SJ, BRZOZOWSKI T, KONTUREK PC, KWIECIEN S, KARCZEWSKA E, DROZDOWICHZ D, STACHURA J, HAHN EG (2000) Helicobacter pylori infection delays healing of ischaemiareperfusion induced gastric ulceration: new animal model for studying pathogenesis and therapy of $H$. pylori infection. Eur J Gastroenterol Hepatol 12:12991313

LEE A, OROURKE J, UNGRIA MC, ROBERTSON B, DASKALOPOULOS G, DIXON MF (1997) A standardized mouse model of Helicobacter pylori infection: introducing the Sydney Strain. Gastroenterol 112:1386-1397

LI H, KALIES B, MELLGARD B, HELANDER HF (1998) A rat model of chronic Helicobacter pylori infection. Scand J Gastroenterol 33:370-378

MULLER I, MEDINA-SELBY A, PALACIOS JL, MARTINEZ P, OPAZO P, BRUCE E, MANCILLA M, VALENZUELA P, YUDELEVICK A, VENEGAS A (2002) Cloning and comparison of tem gene sequences of a Chilean $H$. pylori strain with other $H$. pylori strains revealed higher variability for $\mathrm{VacA}$ and $\mathrm{CagA}$ virulence factors. Biol Res 35:67-84

MARCHETTI M, ARICÒ B, BURRONI D, FIGURA N, RAPPUOLI R, GHIARA P (1995) Development of a mouse model of Helicobacter pylori infection that mimics human disease. Science 267:1655-1658.

MATSUMOTO S, WASHIZUKA Y, MATSUMOTO Y, TAWARA S, IKEDA F, YOKOTA Y, KARITA M (1997) Induction of ulceration and severe gastritis in Mongolian gerbil by Helicobacter pylori infection. J Med Microbiol 46:391-397

MOHAMMADI M, REDLINE R, NEDRUD J, CZINN S (1996) Role of the host in the pathogenesis of Helicobacter-associated gastritis: H. felis infection of inbred and congenic mouse strains. Infect Immun 64:238-245

PAPPO J, TORREY D, CASTRIOTTA L, SAVINAINEN A, KABOK Z, IBRAGHIMOV A (1997) Helicobacter pylori infection in immunized mice lacking major histocompatibility complex class I and class II functions. Infect Immun 67:337-341

RABELO-GONÇALVES EMA, NISHIMURA NF, ZEITUNE JMR (2002) Acute inflammatory response in the stomach of $\mathrm{BALB} / \mathrm{c}$ Mice challenged with coccoidal Helicobacter pylori. Mem Inst Oswaldo Cruz 97:1201-1206

ROSS JS, BUI HX, DEL ROSARIO A, SONBATI H, GEORGE M, LEE CY (1992) Helicobacter pylori: its role in the pathogenesis of peptic ulcer disease in a new animal model. Am J Pathol 141:721-727

SAKAGAMI T, DIXON M, OROURKE J, HOWLETT R, ALDERUCCIO F, VELLA J, SHIMOYAMA T, LEE A (1996) Atrophic gastric changes in both Helicobacter felis and Helicobacter pylori infected mice are host 
dependent and separate from antral gastritis. Gut 39:639-648

SHE FF, LIN JY, LIU JY, HUANG C, SU DH (2003) Virulence of water-induced coccoid Helicobacter pylori and its experimental infection in mice. World $\mathbf{J}$ Gastroenterol 9:520-526

SHOMER NH, DANGLER CA, MARINI RP, FOX JG (1998) Experimental Helicobacter pylori infection induces antral gastritis and gastric mucosa-associated lymphoid tissue in guinea pigs. Infect Immun 66:26142618

SMYTHIES LE, WAITES KB, LINDSEY JR, HARRIS PR, GHIARA P, SMITH PD (2000) Helicobacter pylori-induced mucosal inflammation is Th1 mediated and exacerbated in IL-4, but not IFN- $\gamma$, gene-deficient mice. J Immunol 165:1022-1029

TELFORD JL, GHIARA P, DELLORCO M, COMANDUCCI M, BURRONI D, BUGNOLI M, TECCE MF, CENSINI S, COVACCI A, XIANG Z (1994) Gene structure of the Helicobacter pylori cytotoxin and evidence of its key role in gastric disease. J Exp Med 179:1653-1658

WANG X, STUREGARD E, RUPAR R, NILSSON HO, ALELJUNG PA, CARLÉN B, WILlEN R, WADSTROM T (1997) Infection of BALB/cA mice by spiral and coccoid forms of Helicobacter pylori. J Med Microbiol 46:657-663

WANG $\mathrm{X}$, WILLEN R, SVENSSON M, LJUNG A, WADSTROM T (2003) Two-year follow-up of Helicobacter pylori infection in C57BL/6 and Balb/cA mice. APMIS 111:514-522

WIRTH HP, BEINS MH, YANG M, THAM KT, BLASER MJ (1998) Experimental infection of Mongolian gerbils with wild-type and mutant Helicobacter pylori strains. Infect Immun 66:4858-4866

YAMAOKA Y, KODAMA T, GUTIERREZ O, KIM JG, KASHIMA K, GRAHAM DY (1999) Relationship between Helicobacter pylori iceA, cagA and vacA status and clinical outcome: studies in four different countries. J Clin Microbiol 37:2274-2279 